\title{
A STUDY ON THE THRESHOLD OF VESTIBULAR ORGAN TO MOTION STIMULUS OF SINGLE DIRECTION
}

\author{
By \\ T. MUKASA
From the Department of Oto-Rhino-Laryngology Nagasaki University School of Medicine (Director: Prof. T. Goto)

A stimulating apparatus to give straight movement toward a single direction was devised to test vestibular function, especially function of the ossicles. The lowest threshold of motion sense for straight vertical, lateral and anterior and posterior movement was measured in supine, prone, right and left lateral positions.

In normal adults the lowest threshold in recognizing movement to each direction was between $4 \mathrm{~cm} / \mathrm{sec}^{2}$ and $18 \mathrm{~cm} / \mathrm{sec}^{2}$. Only 2.86 per cent of tested subjects recognized the accelerating motin in $4 \mathrm{~cm} / \mathrm{sec}^{2}$, and all (100 per cent) recognized this motion in $18 \mathrm{~cm} / \mathrm{sec}^{2}$. In regard to the positional difference in motion sense threshold, the sitting position was found to be most sensitive. Among other positions, prone position was most sensitive to vertical and lateral imovement, and lateral position to anterior and posterior movement, when the motion stimulus was below $7 \mathrm{~cm} / \mathrm{sec}^{2}$. If the stimulus was over $7 \mathrm{~cm} / \mathrm{sec}^{2}$, no statistically significant difference was found among various positions.

Influence of uni-or bilateral sound stimulus to motion sense threshold was next studied, revealing elevated threshold of motion sense under loud sound stimulus.

This testing method was applied to a case of unilateral labyrinthine disorder (auditory and vesti. bular dysfunction) and a case of bilateral deafness. As the result elevated threshold or loss of motion sense was found in those who disclosed vestibular dysfunction under ordinary methods.

It was learned by this study that the labyrinth is sensitive to straight motion stimulus and the examination using the swing apparatus is a convenient and clinically useful method to test vestibular function, especially of the ossicles.

\section{直線運動剌戟に対する前庭器の 感覚闘值についての研究}

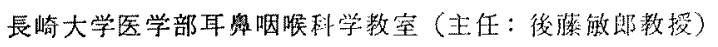 \\ 大学院学生向算朝索站
}

目次

研究目的とその检查方法

検 查成維

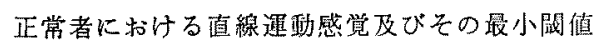

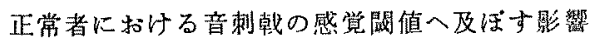

病的状热に抹ける成綪

一側述路障害者及び両側㜔

\section{総括之教掉}

結瑟

交献

人類の平衡器としての前庭迷路の生理には，前庭を反

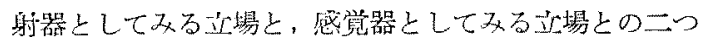
の場会があつて、これによつてとれぞれの研究が行なわ れてきた. Mach 13), Breuer ${ }^{2)}$, Wodak 23), Fischer ${ }^{10)}$, 
Jongkees ${ }^{17}$ ), 松永 ${ }^{47)}$, 渡部 52) 等は迷路を主として感覚 器と見る立場から钼察研究したものである. そのうらで Wodak 23) は前庭迷路の探究は雨者の立場から行なつて いくことが必要であると述ぺている.

前庭迷路機能の観察には回転運動, 直線運動, 傾斜な どの適合刺㦸と, 温度, 電気などの非適合剩㦸が用いら れ，その刺战に対する反応の観察が行なわれているが， 各梙皒についての前庭迷路反応の最小の閾值に関する研 究業績は比較的に少ない, 特に運動感覚の閾値について の報告は更に少ない. 前庭迷路に由来する運動感覚は, Breuer (1874)2), Mach (1875)18) によつて迷路は角加 速度及び各種方向の值線運動を感受すると述べてから, 回耺運動臨覚及び淔線運動感覚とに分子られる。このう ち直線運動感覚については詳細なる加速度閾值の研究に そしい，また Jongkees 15) 等の述べるようにその 検索 には生理的, 物理的ならびに心理的な面からの分折も必 要であり, 最小の加速度閾值の湘定は硎究者により異つ ている.

しかし前庭迷路を平衡感覚器と見做す立場に立つ場合 には，その閾値が問題となる．果してその閾值は他の高 度の感覚器である聴覚と同様に感覚器としての閾値を持 つものかどらか, 著者はこの閾值の問題を研究の目的と した，直線運動刺軲によつて前庭迷路に與奮を宿起させ るためには大体，身体の長軸に対して前後，上下（重 值), 左右 (側方) の刺㦸が用いられている。刺㦸装置 としては Fischer \& Veits ${ }^{21)}$ はエレべーターによる梨 降運動を利用した。 Jongkees \& Groen ${ }^{17)}$, 時実 ${ }^{39)}$, 戸塚 ${ }^{40}$ ), 渡部 52) 等はプランコ装置 (Parallel swing) による往復值線運動を繰返えす加速度刺㦸をとれぞれ用 いている，長谷川 ${ }^{42)}$ 等は上下往復運動刺㦸装置に家鬼 を用いて実験を行なつている。 また向井49) はレール上 の台か゚発条の弾力で水平滑走を行なら装置を作製してい る.

運動感覚は運動自身が感受されるものではなくて, 運 動の方向と速度の变化が感受されるものであつて，等速 運動時には運動感覚は惹起されない.

著者は前庭器性の直線運動感覚とその閾值について探 究するために,ブランコ装置を作製して自临的な值線運 動感覚の検索を行なつた. (1) 水平な位置においての各 方向からの直線運動刺㦸に対して正常な人体の前庭迷路 の閾值を湘定した。（2) 体位（頭位）と刺韩万向との関 係によつて運動感覚がいかに影望されるかを㭘討した。 (3) 音により迷路が刺㦹された場合にその迷路機能がい
かに影響されるか，(4)病的状態における観察として， 一側あるいは両側迷路が障佶された場合の直線運動感覚 の変化をを調ぺた。

\section{I. 検 查対象}

（1）健康成人：本検査に批被検者は当大学勤務 者, 学生, 看櫵学校生徒で聴力は正常, 耳疾患及び眩最 黛 (耳性以外のものも除外した) の既往症のないもの 56 名を用いた（男子18名，女子 38 名）.

また別に音刺㦸による感覚間值への影響を観察するた ぬに10名を用いた（男子6名，女子4名).

(2) 病的状態に打けるもの

a) 一側迷路障害者：聴力検査によつて一側望あるい は一側の高度難聴の確明せるもので, 前庭機能検査によ つて 同側の 前庭機能が 聐失乃至著しく障害されている と思われるもの8名を本㭘査の対象とした．本例は迷路 炎 3 名, 頭部外傷 2 名ならびにメニエル氏病 3 名であつ た.

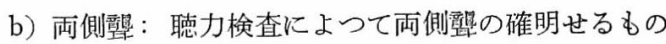
で, 前庭機能検查によつて両側の前庭機能が喪失してい ると思われるもの 2 名, ならびに雨側の前庭機能がほが 正常なるもの1名が本検査の対象となつた。

\section{II. 検査方法}

（1）検查室：本検查は長崎大学医学部耳鼻咽呢科前 庭迷路機能検査室で行ない，感筧を対象とする検査であ るから検查室の恐, 屝を閉鎖し黑幕で可及的に室内を暗 くし、また音望，振動などの影響もひできるだけさけて行 なつた，榆査の実施中は両眼を黒布で覆い視覚の影響が 加わらないよらにした。

（2）検查装置：人体に上下（体軸）, 左右（体軸と值 角)，前後 (脊腹) の各方向に面線運動刺战を就こさ せる装置として, 水平方向の 動摇装置（ブランコ装置 Parallel swing) を作製し使用した(写嗔). 長さ $2.60 \mathrm{~m}$

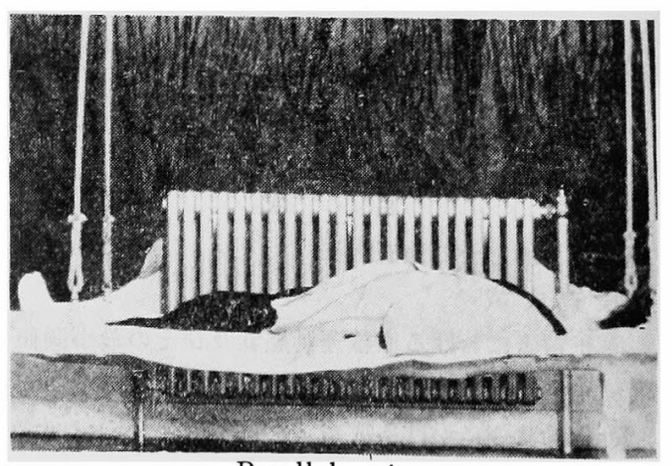

Parallel swing 
の4本の吊り索で平板の载台をつり，㨁線测践は手動で

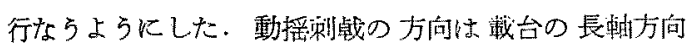

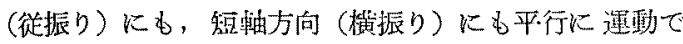
きるよらにした・ブランコの平板载台の下の床に白い目

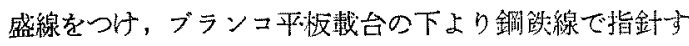
る上らにした，動摇つ周期は被检者をのせたまつで3.0 秒，振湢は可及的水平運動を行なわせるために両方向と もに最大 $18 \mathrm{~cm}$ までとした，吊り索の長さは被检者を 乘せた状態で常に一定になるようにした。被検者の直線 逨動制战に対与る感受の命図のために赤青など数個の色 付きランプを用意した。

(3) 検查の実施法：動摇淩置台汇は身体之の接触を 緩和するた奴毛布を教き，その上に被検者をのせ，体

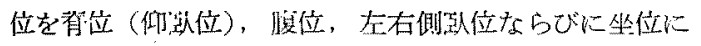

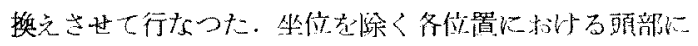

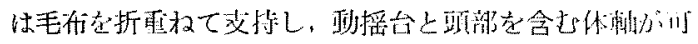

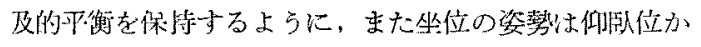

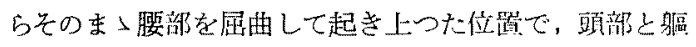

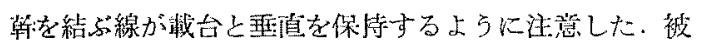
検者の身体は緊膊せず載台にのせ，両眼は黑布で铂つ た。

被检者は精神的, 肉体的条件の泉好なる状態で，食後 をさけて行なつた。

検查は各体位の变换ならびに各運動方向に和いて充分 と思われる一定の間隔（成績の項）をおいて，連続的動 摇のために内藏諸器官など全身の各器官に与之る影䚑を 少くするとつもに，疲労ができるだけおこらない上らに 注意した。

この動摇装置は Parallel swing であるために純粋な

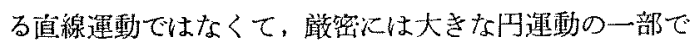
あるが, 台の振愊は曲率半径に比して極めて小さいので 水平面における值線運動であると考えてよい，また一定 の周期で住溴值線㞄動を繰返えしている振子運動は吊り 索の長さが一定であれば振幅が湋つてもその周期（運動 時間)は一定である。しかし振幅が遠光ばその加速度は 異つてくる ${ }^{31)}$ ，この原理から振幅を変元て渵線加速度 $4 \mathrm{~cm} / \mathrm{sec}^{2}, 7 \mathrm{~cm} / \mathrm{sec}^{2}, 11 \mathrm{~cm} / \mathrm{sec}^{2}, 15 \mathrm{~cm} / \mathrm{sec}^{2}, 18 \mathrm{~cm} / \mathrm{sec}^{2}$ の5つを刺㦸として真荷できるようにした。

本検查は自筧的な感覚検查であるから両腿を黒布で㠅 つた被検者を動摇装監台の上に前述の背位の状態に固定 した．次で台を静止状態から柏線加速度 $4 \mathrm{~cm} / \mathrm{sec}^{2}$ で 5 往復，15 秒間制㦸し，動摇が諗知できるかどうかを質 問した。 その後, 战台の長朝方向（従振り）, あるいは
骠㣮方向（横振り）に平行に任意の才问に加速度 $4 \mathrm{~cm}$

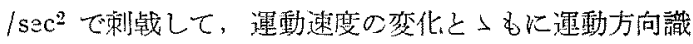
别の認伤があ扎ば，夫々の定つた色付きランプの押しぼ たんをおさせて合図をさせた。本検查に预ける各加速度 の刺㦸時間は 5 往復, 15 秒间とし，各刺㦸，各体位に

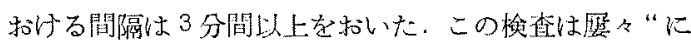
せのあやむつた方向笖覚” のランプを招すので検盀は 数回くり返克して行なつた，加速度 $4 \mathrm{~cm} / \mathrm{sec}^{2}$ で運動感 覚の認租な゙け狆ぱ, $7 \mathrm{~cm} / \mathrm{sec}^{2}$ から $18 \mathrm{~cm} / \mathrm{sec}^{2}$ までの

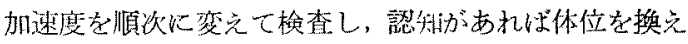

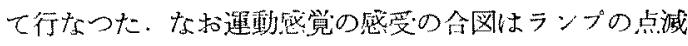

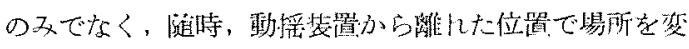

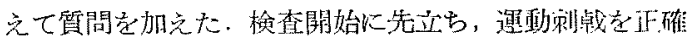
に斵受し得たこと学確信してから応然する上らに注意を 与点た。

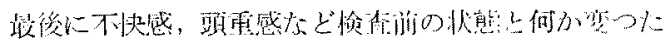

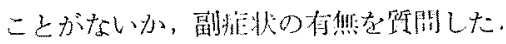

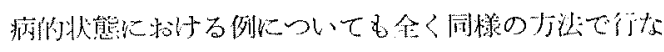

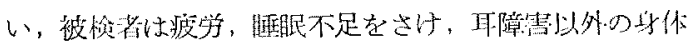
的疾患のない状態の時に行なつた，要に本検查を行なる 前代聴力検查ならびに前庭機能梌查を行なつて迷路機能 を検傠した。

（4）音刺战の感覚間値へ及ぼす影響

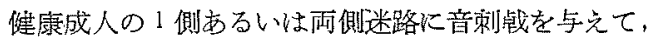
直線運動感覚閾值にいかなる变化が現われるが について観察した，このために小林慗 A-1002 D 型

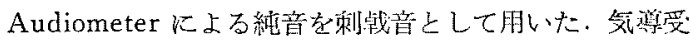
話器を装着して 1000 c.p.s. で $50 \mathrm{db}$ あるいは $90 \mathrm{db}$ を 1 側乃至阿側て㴔かせながら本検查を行ない，音刺此前 の成績上此較㛟㽎したこのため Audiometer の受話 器のコードを長くした。

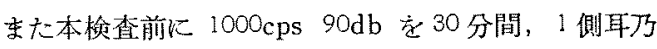

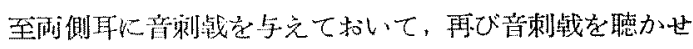
ながら检查を行なつた。

音剌战後偪副症状の有無を質問した。

(5) 前庭機能検查方法

病的状態に打ける例のために用いた前送機能検枯は以 下に述べる方法で行なった。

a）自発朖振検查：Frenzel 上鏡を用いて肉脑的飞钼

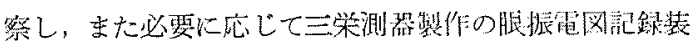

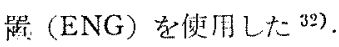

b) 頭位眼振梌查：Frenzel 氏鏡索朋いて坐位，仰

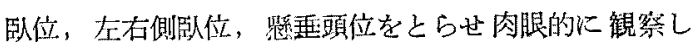


$た^{36)}$

c) 㒛傦の检查

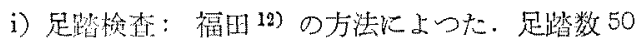

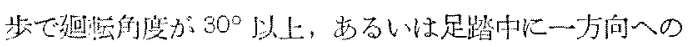
枟㻇傾向を示した場合を病的とみなした。

ii）遮腿雷字法：福田 13) の方法是用いた。一連の

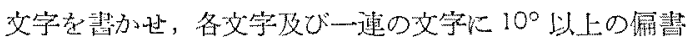
があ机ば病的とみなし，また文学の乱れの有焎をみた。

d) 站㨁り反射㭘盉

i) 起卉㭇查：Romberg's test Mann's test

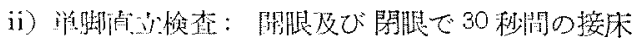

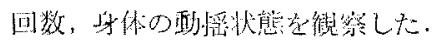

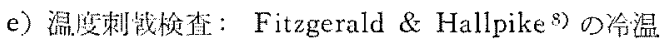

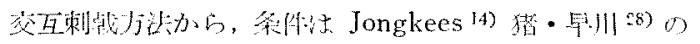

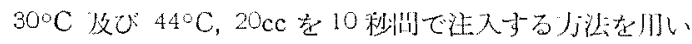
た、镮祭は前述の（ENG）記録老用いた299)。

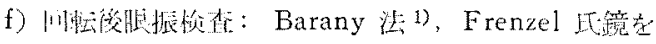

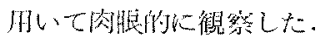

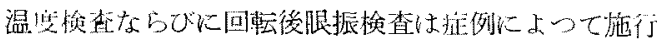
したものとしないものがある。

(6) 德力梌查

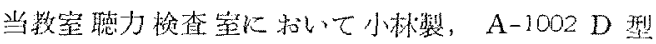
Audiometerを用いて行なつた。

\section{III. 検查成績}

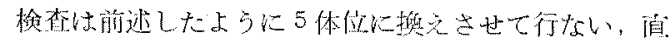

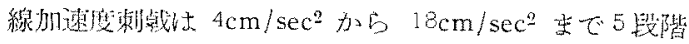

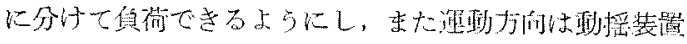

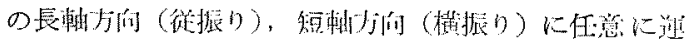
䎟させた。

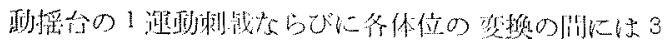

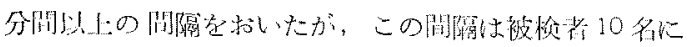

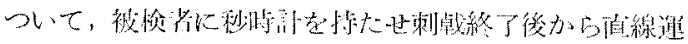

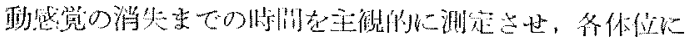

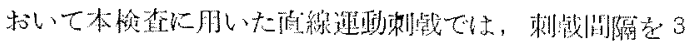
分以上和けぱよいことがわかつた。

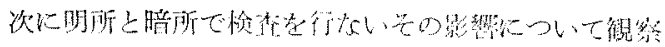

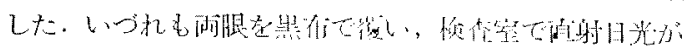

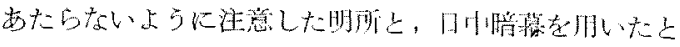

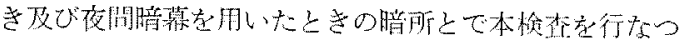

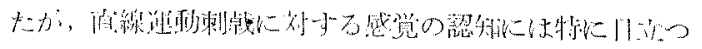

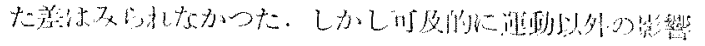

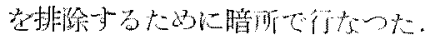

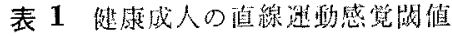

\begin{tabular}{|c|c|c|c|c|c|c|c|c|c|c|}
\hline \multirow{2}{*}{ No. } & \multicolumn{2}{|c|}{ 拝 位 } & \multicolumn{2}{|c|}{ 腹 位 } & \multicolumn{2}{|c|}{ 坛隹位 } & \multicolumn{2}{|c|}{ 左蜎位 } & \multicolumn{2}{|c|}{ 坐 } \\
\hline & C & (短) & (長) & & (長 & ( ( 短) & $1(E)$ & (短) & (無) & (短) \\
\hline 1 & b & b & $c$ & c & $\mathrm{d}$ & $c$ & d & c & a & b \\
\hline 2 & $\mathrm{~d}$ & c & $\mathrm{e}$ & $\mathrm{e}$ & $\mathrm{e}$ & e & $\mathrm{e}$ & $d$ & $\mathrm{~b}$ & $b$ \\
\hline 3 & c & $\mathrm{c}$ & $c$ & $\mathrm{~d}$ & $\mathrm{c}$ & $d$ & $\mathrm{~d}$ & $\bar{d}$ & $\mathrm{c}$ & c \\
\hline 4 & $\mathrm{~b}$ & $\mathrm{~d}$ & $c$ & $\mathrm{c}$ & $\mathrm{d}$ & $\mathrm{c}$ & $\mathrm{c}$ & $\mathrm{d}$ & b & $\mathrm{c}$ \\
\hline 5 & c & d & c & c & c & $c$ & c & $c$ & $\mathrm{c}$ & c \\
\hline 6 & b & $c$ & $b$ & b & b & c & $b$ & b & $\mathrm{a}$ & $\mathrm{c}$ \\
\hline 7 & $\mathrm{c}$ & c & b & c & $c$ & b & $b$ & b & b & b \\
\hline 8 & a & b & a & c & c & b & $\mathrm{b}$ & b & $\mathrm{b}$ & a \\
\hline 9 & $\mathrm{~b}$ & $\mathrm{c}$ & $c$ & e & $c$ & e & c & e & $a$ & $a$ \\
\hline 10 & a & $\mathrm{a}$ & a & a & a & a & $\mathrm{a}$ & a & $a$ & a \\
\hline 11 & b & $\mathrm{c}$ & $b$ & b & b & b & b & $\mathrm{b}$ & $\mathrm{a}$ & b \\
\hline 12 & $c$ & e & c & c & $\mathrm{b}$ & c & c & d & $\mathrm{b}$ & c \\
\hline 13 & d & c & $d$ & c & d & $c$ & d & c & $c$ & b \\
\hline 14 & a & b & c & $\mathrm{c}$ & c & $c$ & $\mathrm{c}$ & $\mathrm{c}$ & a & $\mathrm{a}$ \\
\hline 15 & $\mathrm{e}$ & e & $e$ & e & e & $\mathrm{e}$ & e & $\mathrm{e}$ & e & e \\
\hline 16 & $\mathrm{c}$ & c & c & $\mathrm{e}$ & d & e & $\mathrm{d}$ & b & $\mathrm{b}$ & b \\
\hline $1 \%$ & $\mathrm{c}$ & c & d & $\mathrm{c}$ & $\mathrm{c}$ & c & $\mathrm{d}$ & $\mathrm{c}$ & b & $\mathrm{b}$ \\
\hline 16 & c & c & c & d & $c$ & $\mathrm{~d}$ & c & c & a & $\mathrm{b}$ \\
\hline 19 & b & $c$ & c & c & $c$ & $c$ & $c$ & $\mathrm{~d}$ & b & c \\
\hline 20 & c & c & d & d & c & c & c & e & $b$ & $b$ \\
\hline 21 & C & $c$ & c & c & c & c & c & c & b & c \\
\hline 22 & b & c & b & $\mathrm{c}$ & $c$ & d & c & c & b & $\mathrm{b}$ \\
\hline 23 & c & d & c & d & $d$ & c & d & $\mathrm{c}$ & c & c \\
\hline 24 & c & c & c & c & c & c & $c$ & c & b & $c$ \\
\hline 25 & b & $\mathrm{c}$ & b & b & b & c & c & c & a & $\mathrm{a}$ \\
\hline 26 & $c$ & $c$ & $\mathfrak{e}$ & $\mathrm{d}$ & $c$ & $c$ & $c$ & $d$ & $c$ & $b$ \\
\hline 27 & c & c & e & e & $\mathrm{d}$ & c & e & c & b & c \\
\hline 28 & d & e & d & $\mathrm{c}$ & $\mathrm{d}$ & e & $\mathrm{d}$ & d & d & $\mathrm{d}$ \\
\hline 29 & $\mathrm{c}$ & d & b & c & $\mathrm{c}$ & c & b & c & a & $\mathrm{a}$ \\
\hline 30 & b & b & c & c & $\mathrm{c}$ & b & c & b & $b$ & a \\
\hline 31 & c & c & $\mathrm{d}$ & c & $\mathrm{d}$ & c & d & $c$ & b & c \\
\hline 32 & b & b & c & c & $\mathrm{d}$ & c & $\mathrm{d}$ & $c$ & b & c \\
\hline 33 & $c$ & $c$ & $c$ & d & e & $c$ & e & $c$ & $c$ & $b$ \\
\hline 34 & $c$ & d & $\mathrm{d}$ & e & e & $\mathrm{d}$ & d & e & c & d \\
\hline 35 & $\mathrm{c}$ & b & d & c & $\mathrm{d}$ & b & d & $\mathrm{d}$ & $b$ & d \\
\hline 36 & $c$ & c & $\mathrm{d}$ & d & d & c & $\mathrm{d}$ & c & c & c \\
\hline 37 & b & b & a & b & b & a & $\mathrm{b}$ & a & a & b \\
\hline 38 & c & e & c & c & $\mathrm{d}$ & $\mathrm{d}$ & d & c & b & c \\
\hline 39 & d & $\mathrm{d}$ & c & c & c & c & c & c & c & c \\
\hline 40 & b & $c$ & $c$ & c & $c$ & $c$ & c & $\mathrm{b}$ & $b$ & $\mathrm{c}$ \\
\hline 41 & c & 0 & c & d & c & c & c & c & b & c \\
\hline 42 & 2 & b & $\mathrm{b}$ & b & $b$ & b & b & b & $\mathrm{b}$ & b \\
\hline 43 & c & $\mathrm{d}$ & b & c & d & $\mathrm{c}$ & c & b & $\mathrm{d}$ & c \\
\hline 44 & b & b & b & c & d & c & $\mathrm{c}$ & $c$ & $\mathrm{~b}$ & $\mathrm{~b}$ \\
\hline 45 & d & e & $d$ & d. & d & e & $\mathrm{d}$ & $\mathrm{d}$ & $c$ & $\mathrm{~b}$ \\
\hline 46 & b & b & d & c & c & c & e & c & b & c \\
\hline 47 & b & $b$ & $c$ & $c$ & c & b & c & c & c & $\mathrm{b}$ \\
\hline 48 & c & c & L & c & d & $\mathrm{e}$ & $\mathrm{d}$ & $\mathrm{d}$ & $c$ & e \\
\hline 49 & b & b & c & c & c & b & c & b & c & $b$ \\
\hline 50 & c & b & $\mathrm{b}$ & b & $\mathrm{b}$ & c & $\mathrm{b}$ & b & $\mathrm{b}$ & b \\
\hline 51 & b & c & $\mathrm{b}$ & $\mathrm{b}$ & b & $\mathrm{b}$ & b & $b$ & $\mathrm{~b}$ & $\mathrm{~b}$ \\
\hline 52 & c & $d$ & $\mathrm{~d}$ & c & c & $\mathrm{e}$ & d & c & $\mathrm{c}$ & $\mathfrak{c}$ \\
\hline 53 & b & a & $\mathrm{b}$ & $\mathrm{b}$ & c & c & b & $\mathrm{b}$ & b & $\mathrm{c}$ \\
\hline 54 & d & d & $c$ & $d$ & e & $\mathrm{d}$ & e & d & b & $\mathrm{c}$ \\
\hline 55 & $\mathrm{c}$ & $d$ & $\mathrm{~d}$ & $\mathrm{c}$ & b & $\mathrm{b}$ & b & $b$ & b & b \\
\hline 56 & e & e & $\mathrm{e}$ & $\mathrm{e}$ & $\mathrm{d}$ & $\mathrm{d}$ & e & d & c & $\mathrm{c}$ \\
\hline
\end{tabular}

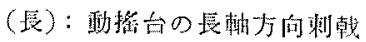

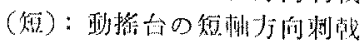
a: 川速度 $4 \mathrm{~cm} / \mathrm{sec}^{2}$
b: 加数俈 $7 \mathrm{~cm} / \mathrm{sec}^{2}$
c: $11 \mathrm{~cm} / \mathrm{sec}^{2}$
e: $18 \mathrm{~cm} / \mathrm{sec}^{2}$ 
表 2 梿康成人の植線運軘感觉（闑值） の感受率 $(\%)$

\begin{tabular}{|c|c|c|c|c|c|c|}
\hline & & $\begin{array}{l}4 \mathrm{~cm} \\
/ \mathrm{sec}^{2}\end{array}$ & $\begin{array}{l}7 \mathrm{~cm} \\
/ \mathrm{sec}^{2}\end{array}$ & $\begin{array}{l}11 \mathrm{~cm} \\
1 / \mathrm{sec}^{2}\end{array}$ & $\begin{array}{r}15 \mathrm{~cm} \\
\quad / \mathrm{sec}^{\circ} \\
\end{array}$ & $\begin{array}{l}18 \mathrm{~cm} \\
1 \mathrm{sec}^{2}\end{array}$ \\
\hline \multirow{2}{*}{ 脊 位 } & (器) & $5.4 \%$ & $32.2 \%$ & $48.2 \%$ & $10.7 \%$ & $3.5 \%$ \\
\hline & (短) & 3.5 & 23.2 & 42.8 & 17.9 & 12.5 \\
\hline \multirow{2}{*}{ 腹 位 } & (艮) & 5.4 & 21.4 & 44.7 & 21.4 & 7.1 \\
\hline & (短) & 1.8 & 14.3 & 53.5 & 17.9 & 12.5 \\
\hline \multirow{2}{*}{ 左卧位 } & (長) & 1.8 & 16.1 & 41.0 & 30.4 & 10.7 \\
\hline & (短) & 3.5 & 17.9 & 50.0 & 12.5 & 14.3 \\
\hline \multirow{2}{*}{ 右卧位 } & (㩲) & 1.8 & 21.4 & 37.5 & 28.6 & 10.7 \\
\hline & (短) & 3.5 & 25.0 & 42.8 & 21.4 & 7.1 \\
\hline \multirow{2}{*}{ 坐 位 } & (舆) & 17.9 & 48.2 & 28.6 & 3.5 & 1.8 \\
\hline & (短) & 14.3 & 39.5 & 39.5 & 3.5 & 3.5 \\
\hline
\end{tabular}

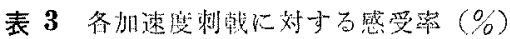

\begin{tabular}{|c|c|c|c|c|c|}
\hline & $\begin{array}{l}4 \mathrm{~cm} \\
/ \mathrm{sec}^{2}\end{array}$ & $\begin{array}{l}7 \mathrm{~cm} \\
1 \mathrm{sec}^{2}\end{array}$ & $\begin{array}{l}1 / \mathrm{cm} \\
1 / \mathrm{sec}^{2}\end{array}$ & $\begin{array}{c}15 \mathrm{~cm} \\
1 \mathrm{sec}^{2}\end{array}$ & $\begin{array}{c}18 \mathrm{~cm} \\
1 \mathrm{sec}^{2}\end{array}$ \\
\hline \multirow{2}{*}{ 昘 位 } & $5.4 \%$ & $37.6 \%$ & $85.8 \%$ & $96.5 \%$ & $100 \%$ \\
\hline & 3.3 & 26.7 & 69.5 & 87.4 & 100 \\
\hline \multirow{2}{*}{ 腹 位 } & 5.4 & 26.8 & 71.5 & 92.9 & 100 \\
\hline & 1.8 & 16.1 & 69.6 & 87.5 & 100 \\
\hline \multirow{2}{*}{ 左啹俏 } & 1.8 & 17.9 & 58.9 & 89.3 & 100 \\
\hline & 3.5 & 21.4 & 71.4 & 83.9 & 100 \\
\hline \multirow{2}{*}{ 在视位 } & 1.8 & 23.2 & 60.7 & 89.3 & 100 \\
\hline & 3.5 & 28.5 & 71.3 & 92.7 & 100 \\
\hline
\end{tabular}

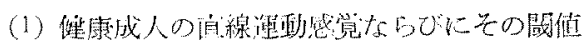

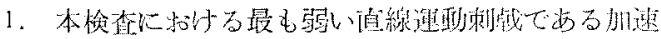

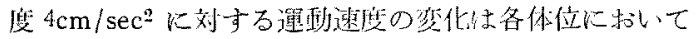

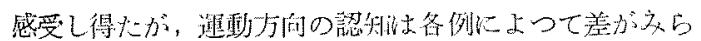
れた。

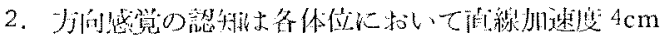

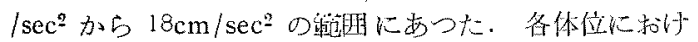

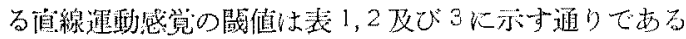
か，山下これについて述べる。

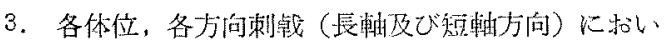
て本检查に拈ける最小心加速度閶值である $4 \mathrm{~cm} / \mathrm{sec}^{2}$ 老

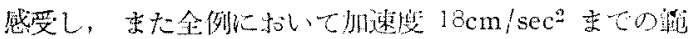

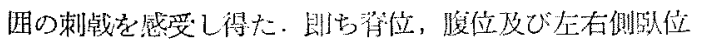

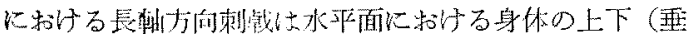

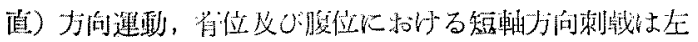

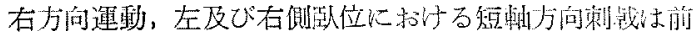

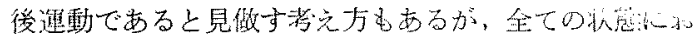

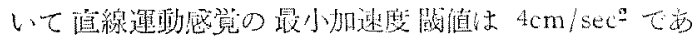

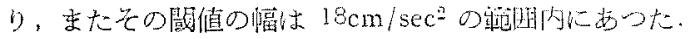

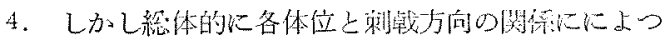

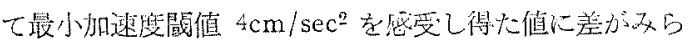

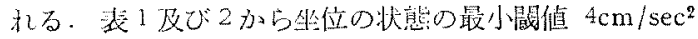
の臨受率加率い

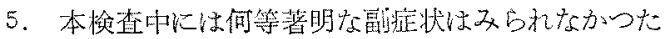

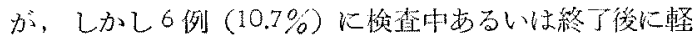

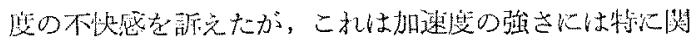

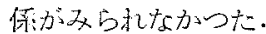

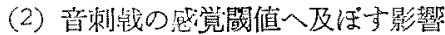

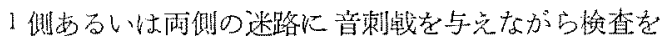

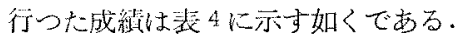

1. $1000 \mathrm{cps} 50 \mathrm{db}$ ．の音刺㦸では刺㦸前の成績と比䩙 して差異が諗められたい。

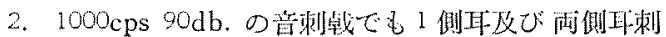

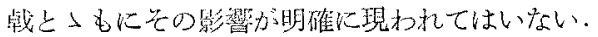

3. 初わに1僋あるいは阔側耳に 1000 cps $90 \mathrm{db}$. の

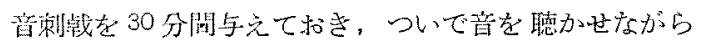

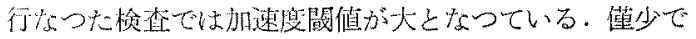
はするが影型があるように思执る。

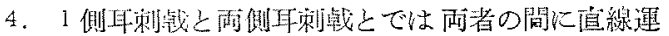

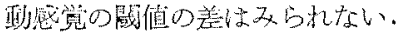

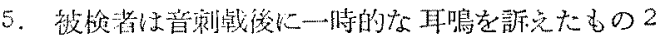

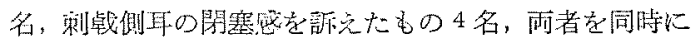

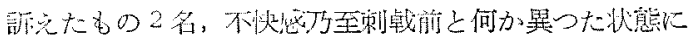

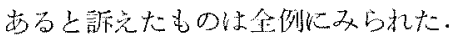

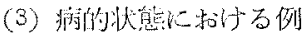

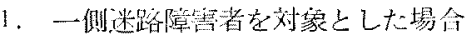

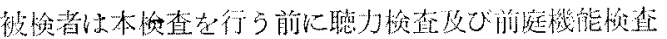

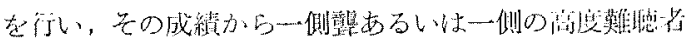

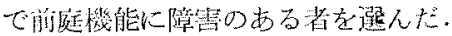

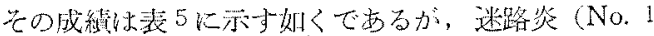

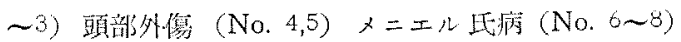

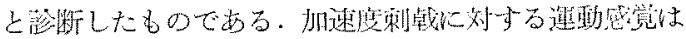

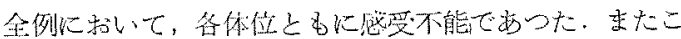

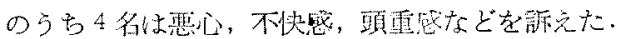

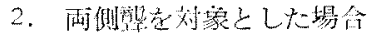

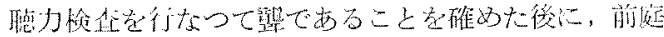

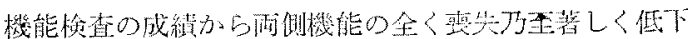

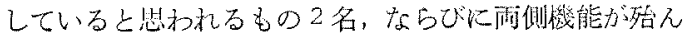




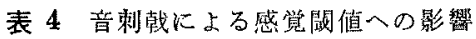

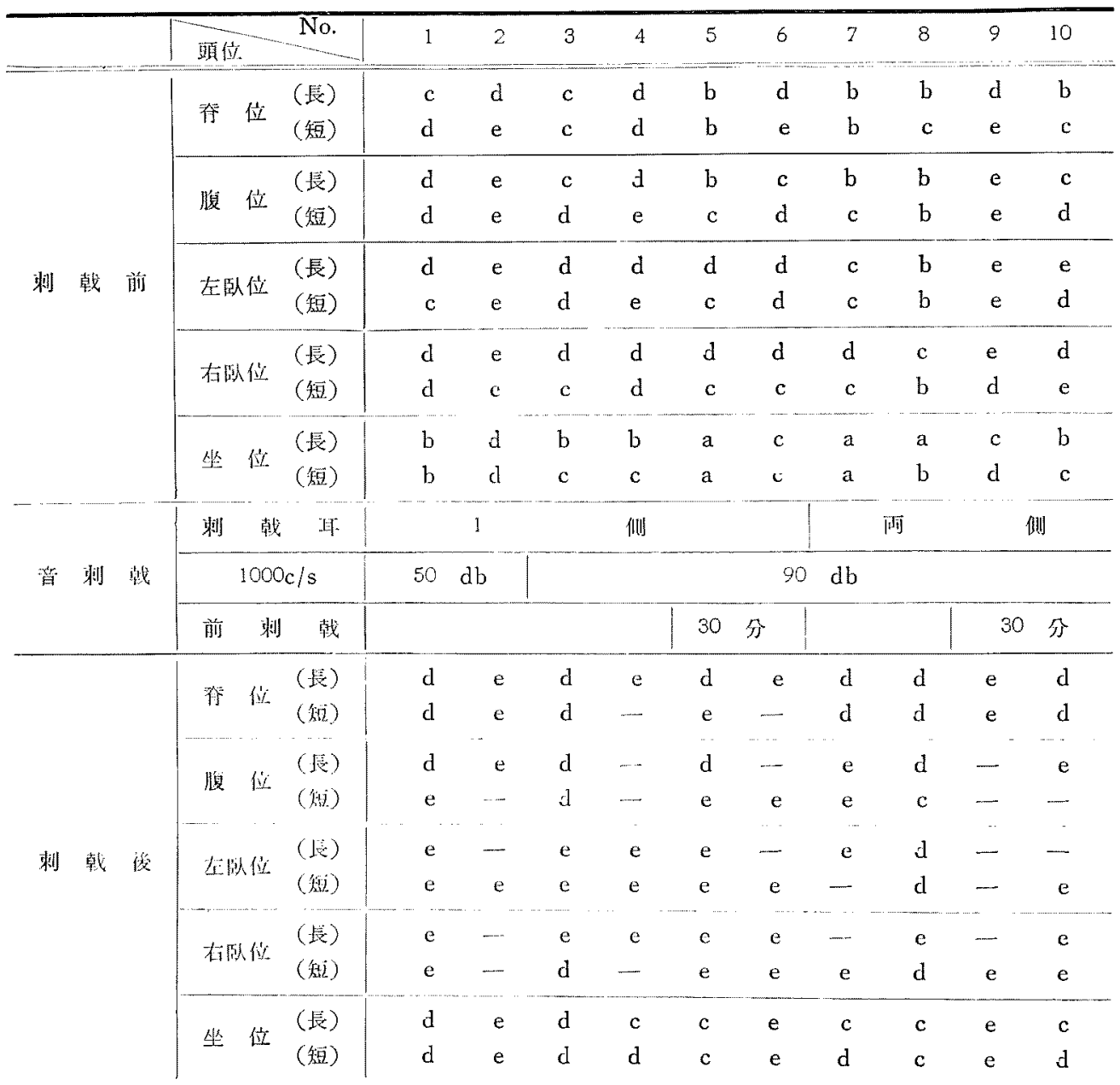

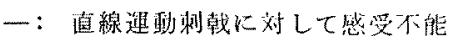

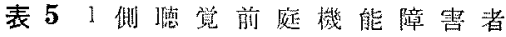

\begin{tabular}{|c|c|c|c|c|c|c|c|c|c|c|c|c|c|c|}
\hline \multirow{2}{*}{ No. } & \multirow{2}{*}{ 年令 } & \multirow{2}{*}{ 雉 } & \multirow{2}{*}{ 將 } & \multirow{2}{*}{\multicolumn{2}{|c|}{ 耳. }} & \multirow{2}{*}{\multicolumn{2}{|c|}{ 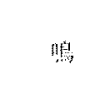 }} & \multicolumn{3}{|c|}{ 前 } & 倬 & \multicolumn{3}{|c|}{ 查 } \\
\hline & & & & & & & & S.N & L.N & 退 踏 & 㥜 䆘 & 柱 & 拄 率 & 温 \\
\hline 1 & 23 & 右 & 耳 & 右 & 14 & 続 & 性 & $\theta$ & $\theta$ & 右 偪 & 右 偏 & $(+)$ & $(+)$ & 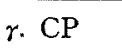 \\
\hline 2 & 31 & 左 & 耳 & 左 & 特 & 経 & 件: & $\stackrel{\leftrightarrow}{\longrightarrow}$ & $\begin{array}{ll}\text { 亲 } & \vdots \\
\text { 致 } & \vdots\end{array}$ & 左 侢 & 左 保 & $(+)$ & $(+)$ & l. CP \\
\hline 3 & 22 & 右 & 耳 & 右 & 断 & 綂 & 性 & $\theta$ & $\theta$ & $(-)$ & 有 偏 & $(t)$ & $(t)$ & $\gamma \cdot \mathrm{CP}$ \\
\hline 4 & 45 & 右 & 耳 & 右 & 持 & 綂 & 性 & $\theta$ & $\theta$ & 右 偏 & 右 偏 & $(+)$ & $(+)$ & $\gamma \cdot \mathrm{CP}$ \\
\hline 5 & 51 & 左 & 耳 & 左 & 持 & 綂 & 性 & $\theta$ & $\theta$ & 至 确 & $(-)$ & $(-)$ & $(t)$ & $\begin{array}{l}\mathrm{CP}+ \\
\text { 病侧 DP }\end{array}$ \\
\hline 6 & 31 & tr & 耳 & & 断 & 統 & 性 & $\theta$ & $\theta$ & 灰: 傮 & 至 确 & $(+)$ & $(+)$ & l. $\mathrm{CP}$ \\
\hline 7 & 51 & 有 & 4 & ts & & & $\mathrm{L}$ & $\theta$ & $\theta$ & 柱 倠 & $(-)$ & $(+)$ & $(+)$ & $\gamma \cdot \mathrm{CP}$ \\
\hline 8 & 41 & 左 & $\mathrm{F}$ & & 䉼 & 稆 & 性: & $\theta$ & $\theta$ & 至 偏 & 在 俏 & $(+)$ & $(+)$ & l. $\mathrm{CP}$ \\
\hline
\end{tabular}

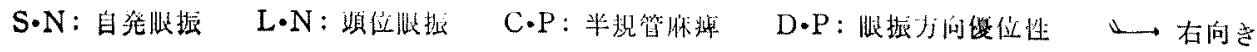


表 6 両侧熊の前庭機能

\begin{tabular}{|c|c|c|c|c|c|c|c|c|c|}
\hline No. & 和令 & S.N & L.N & 踏 & 临字 & 起 I & 閌 & 度 & 回 \\
\hline 1 & 48 & $\theta$ & $\theta$ & 僻倚なし & 偏慧なし & $( \pm)$ & 䦥罒で(十) & 两側の反志なし & 阿側の爻比なし \\
\hline 2 & 23 & $\theta$ & $\theta$ & " & " & $(+)$ & $(t)$ & " & " \\
\hline 3 & 19 & $\theta$ & $\theta$ & $(-)$ & $(-)$ & $(-)$ & $( \pm)$ & D.P & if. \\
\hline
\end{tabular}

（十）異常 习琶ム

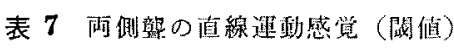

\begin{tabular}{|c|c|c|c|c|c|c|c|c|c|c|}
\hline \multirow{2}{*}{ No. } & \multicolumn{2}{|c|}{ 奉 位 } & \multicolumn{2}{|c|}{ 腹 位 } & \multicolumn{2}{|c|}{ 左卧位 } & \multicolumn{2}{|c|}{ 右臥位 } & \multicolumn{2}{|c|}{ 坐 位 } \\
\hline & (長) & 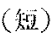 & (長) & ( & (垅) & (知) & (1) & (焙) & (長) & (知) \\
\hline 1 & - & - & - & - & - & - & - & - & - & - \\
\hline 2 & - & - & - & - & - & - & - & - & - & - \\
\hline 3 & $\mathrm{c}$ & $\mathrm{d}$ & $\mathrm{d}$ & $\mathrm{d}$ & $\mathrm{e}$ & $\mathrm{d}$ & $\mathrm{d}$ & d & $\mathrm{c}$ & $\mathrm{c}$ \\
\hline
\end{tabular}

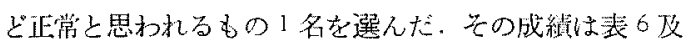
び7に示す通りである。

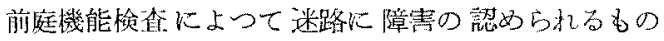

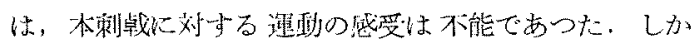

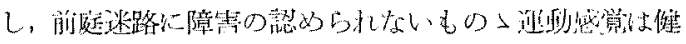

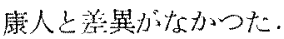

\section{総括亡考按}

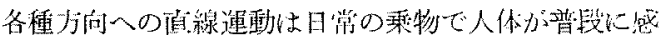

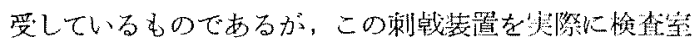

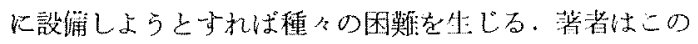

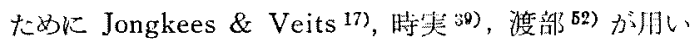
たブランコ䒾置化よつて值線運動を苦起させるようにし た.しかし同じブランコ蒋置で直線加速度刺战は一茯で

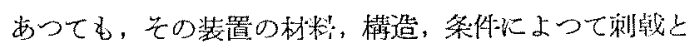
しては幾分の差異が生じて、ることは否定できないと思

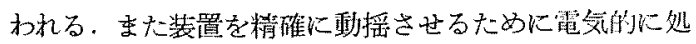

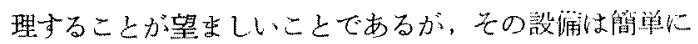
はできないこのために淔線媈動证㦸は手動で行つた。

最近をで Barany の国転刺戟炕よる眼振の観祭は生て 手動で行なわれ，朴沢は前庭機能検査法の1つであるク

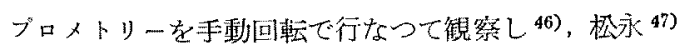

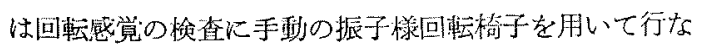
つた。これらの研究によつて手動による剌韩によつても 充分なる检查が行なるることが䈍められる。

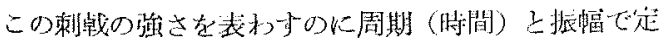

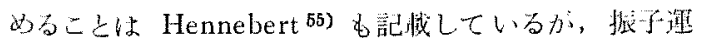

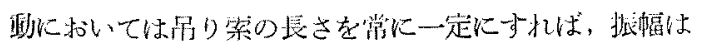

異つても周期 (時間) は一定となるから，種々に拨幅を

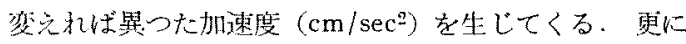

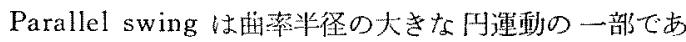
るから，振幅が小さい程正確に水平值線媈動を行ならも のである。これらの点から薯者は周期・3秒，振幅・最 大 $18 \mathrm{~cm}$, 剩㦸時間・15 秒間, 加速度 $4,7,11,15,18$ $\mathrm{cm} / \mathrm{sec}^{2}$ t定めた。

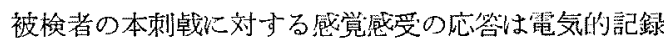
が記録紙の上に描写できれば申し分はないが，これも

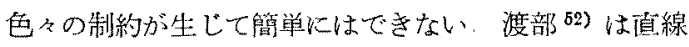
運動感覚の檢查に和いてすべての応答を被檢者と口智に よつて行なつている。しかしこれは渡部も述べている上

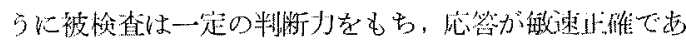

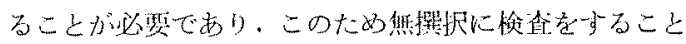

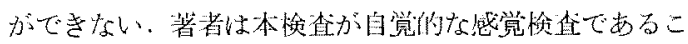
こから，現在用いら机ている Audiometerによる埴小

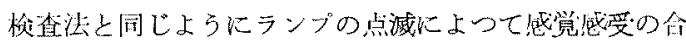

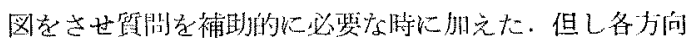
の進動刺㦸の感受を区别するために数個の色付きランブ を用いた。

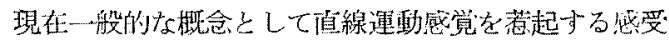
装置は前珽迷路の耳石器にあり。その與奮は前运神経，

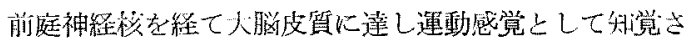

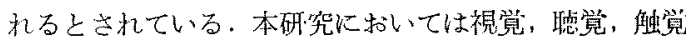
などのいわゆる判別州咸覚 (epicritic sensation) の惑 覚器，ならびに前庭器以外の队缄，痛覚などのいわいる 原始留筧 (protopathic sensation) の感覚器 ${ }^{38}$ ) 3.50 インブルスは除外し得たものと考党てゆきたい，

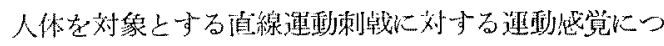
いての報告は Mach ${ }^{18)}$, Veits ${ }^{21)}$, Fischer ${ }^{11)}$, Bourdon 34), Jongkees ${ }^{17)}$, 渡部 ${ }^{52)}$ 等によつて行なわ扎ている。

前庭迷路をプランコ装置を用いて直線傕動刺㦸を加え

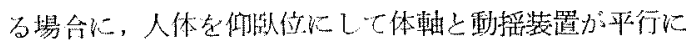

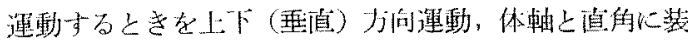

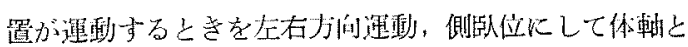




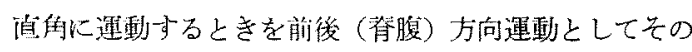
反応を種々の方法で観繁した報告は散見される。

- - 万 Howlett 24), Jongkees ${ }^{17)}$, Groen ${ }^{20)}$,三沢 ${ }^{49)}$ ( 乘物酥に刘して最も安定した頙位を探究し，頭位によつ て遇動感筧が異つてくることを報告している

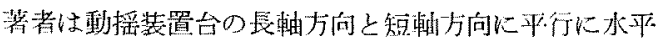

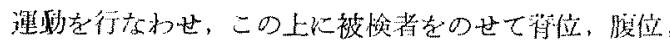
左及び右側呺位，ならびに坐位の各䫓位をしらせたが，

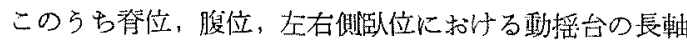

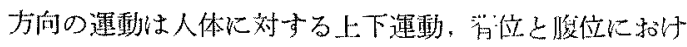

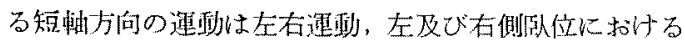

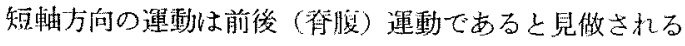
がここらの運動は人体を水平面に置いた状態の運動

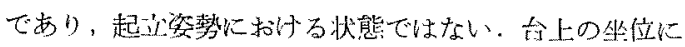

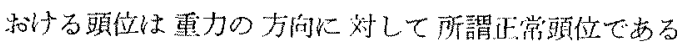

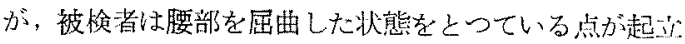
资勢と異つている。

Hulk-Henkes ${ }^{25)}$, Howlett ${ }^{24)}$, Noble 27) は闬庭迷路

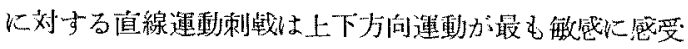

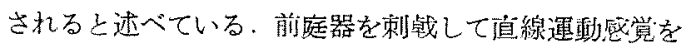

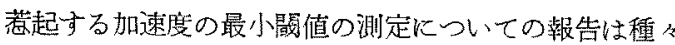
行なわれているが，その测定值は研器者によつて多少異 つている、Veits ${ }^{21) ~}$

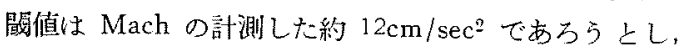
Bourdon ${ }^{34)}$ も同様に $12 \mathrm{~cm} / \mathrm{sec}^{2}$ であるとした．Jongkees \& Groen ${ }^{17)}$ は Parallel swing k上る测定で水

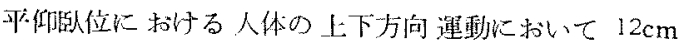
/ $\sec ^{2}$ であると述へ，また Kunze ${ }^{34)}$ は水平方向霾動で

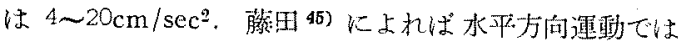

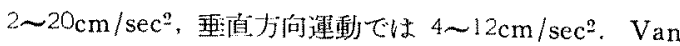
Egmond ${ }^{20)}$ は加速度の䦨值は $10 \mathrm{~cm} / \mathrm{sec}^{2}$ この上5K 加速应の閾値は文献に上つて相当の幅が办られる。

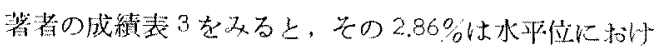

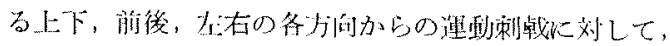
骎小の为速刺战である $4 \mathrm{~cm} / \mathrm{sec}^{2}$ が或受されている。

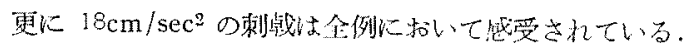

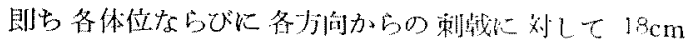

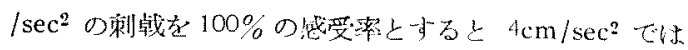
$2.86 \%, 7 \mathrm{~cm} / \mathrm{sec}^{2}$ では $17.24 \%, 11 \mathrm{~cm} / \mathrm{sec}^{2}$ てい 55.87 $\%, 15 \mathrm{~cm} / \mathrm{sec}^{2}$ では71.95\%の割合で加速陵を咸受して いる.

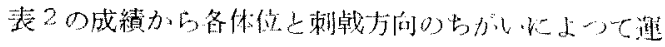

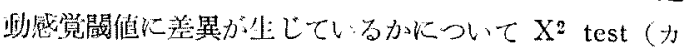

イ自乗テストづクよつて算定した。この結果, 表 20 の成績からは坐位と他の4体位との間に有意の差䔬が認

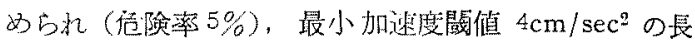

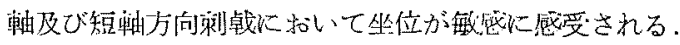

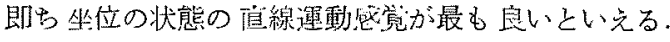
他の4体位相互を比較してみたが有意の差異は裙められ なかつた．上つてこの4䫒位について7,11,15,18cm $1 \mathrm{sec}^{2}$ の加速度について観察することつした。. $18 \mathrm{~cm} / \mathrm{sec}^{2}$ の加速度刺㦸の感受はいずれも $100 \%$ であるが，很条の

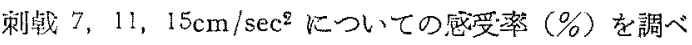
(表3)、これを $\mathrm{X}^{2}$ test で算定した。

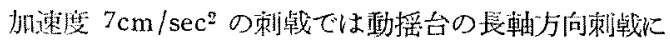

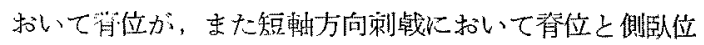

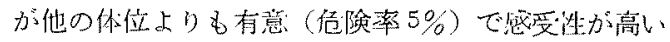

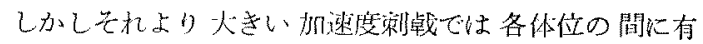

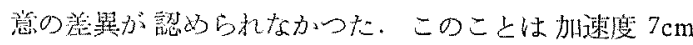

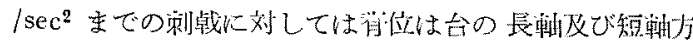

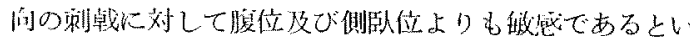

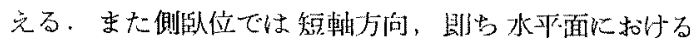

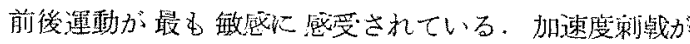
$7 \mathrm{~cm} / \mathrm{sec}^{2}$ より大きくなれば各体位の間の卢線連動緊觉 には差異が䛃められていない

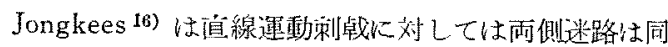
時に同性質の刺㦸をらけて自線運動を感受するから，敏 感な感要のためには啊側迷路機能が侹全でなけれはなら

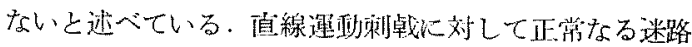

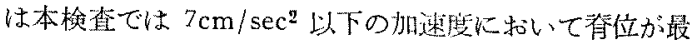

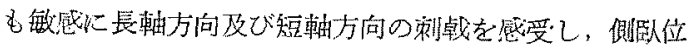

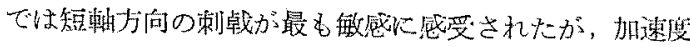

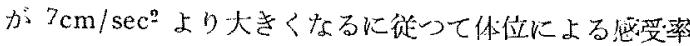
の美異は消失したこのことは坐位以外の体位について

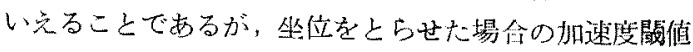
の成繢が他の休位をとらせた場含よりも度いことは，坐

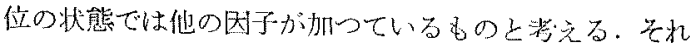
は坐位と他の体位の成績をみるとはなはだしく坐位の場

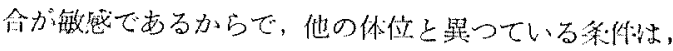

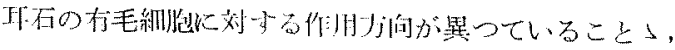
身体が腰部で属曲しているために身体を一定の件位に支

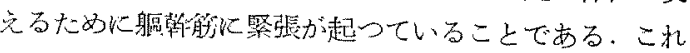

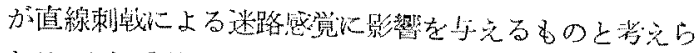

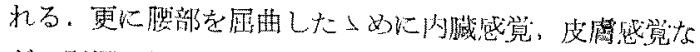

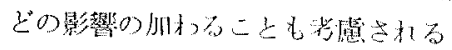

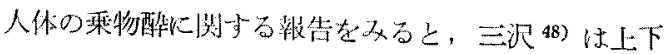




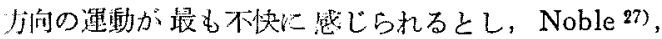
Groen \& Jongkees ${ }^{17)}$ ( 仰卧位汇括ける上下方向の直

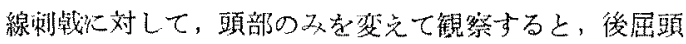
位をとらせたときが最む感受性が低下すると報告してい る.この理由として Groen \& Jongkees は耳右器官に Quix に上る盲点 (the blind spot) の存在を仮定し， 後屈頭位をとらせると，そこに加速度が作用するからで あると説明しているが，Grahe, Fischer 9) 等はこのよ らな位置をとつた際には頭部へ行く血管の圧迫又は内缄 の荤らによる影響のために平衡感覚汇銷誤をきたすから であると説明している.耳右器官の盲点山頭部を後方へ 傾けた時にのみ反応するるのか，他の頭位では反応しな いものか，盲点とのものにも具体的な証明がない。

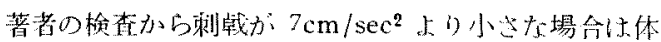

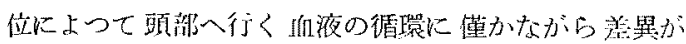
生し，こ礼が前庭迷路の感菜置に影響を与老，刺㦸が $7 \mathrm{~cm} / \mathrm{sec}^{2}$ より大きくなつ大場合には各体位の間に和い $て X^{2}$ test に差異が言められなからた。これは加速度 $18 \mathrm{~cm} / \mathrm{sec}^{2}$ において各体位及び剩韩方向に関倸なく全例

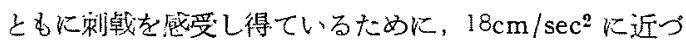
くほど成績值に差晎が現れにくななつている。

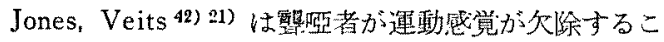
とを報告し，Mach，Breuer 》（は迷路法各種方向の淔線 運動を感受するが，その装置は耳右器官にあると述べ た. Magnus \& de Klijn ${ }^{42)}$ は直線媈動は半規管で感 受されると述べたが，Fischer，Veits ${ }^{22)}$ は倬線運動に 特けるリンパ流動説を否定している，Quix 42) は重渲方

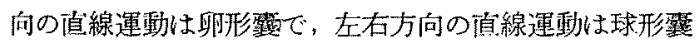
によつて感受されるとしたが，長谷川 42）は人体に批い，

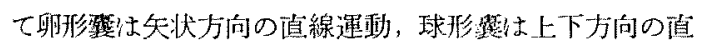
線渾動を感受すると述べている。

解剖学的取右器官の位置闺係をみると迷路の前庭内

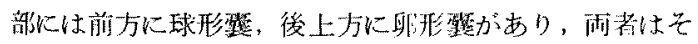

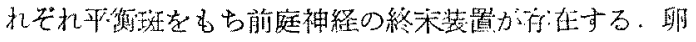

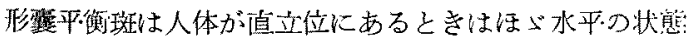

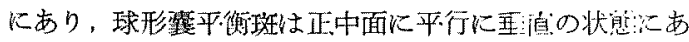
る.この2つの平便斑の機能については Mach, Breuer Magnus，Quix 等によつて解釈に多少の差翼があるが， いずれる䫀性によつて平微砂のずれが神経終夈への刺㦸 上なるものと解积されている33)。

Maxwell 26) ( 6:3) は蛙を用いて耳石器上半規管の機能に関捙性がある こ上を教告している，解剖学的に耳右器官と半規管と山
異つたものであつても，人体の斗右器官の及を刺㦸する ことはきわかて因難である.

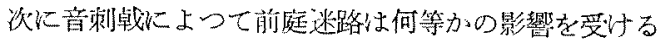
か否かについての交献を探すと，Temkin ${ }^{54)}$ は騒音に

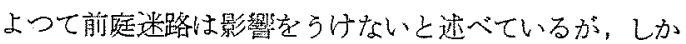

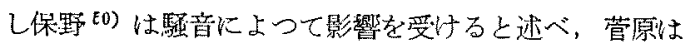

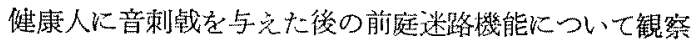
した ${ }^{36)}$. 即ち 1 側耳に音刺战を与えると書字に偏倚が現

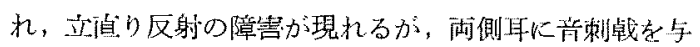

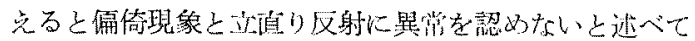
いる.

著者は音刺㦸によつて前庭迷路の煊線連動感覚閾值が いか影響されるかを観察したが，Audiometer 1000

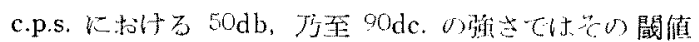

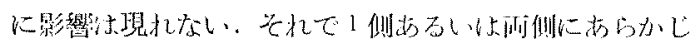

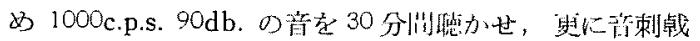
を加えながら上述の检査を行なつた。

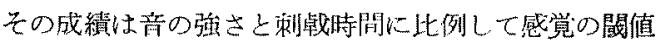
が大きくなつてくることを示した。こ机は一側及び両側 いずれの刺战の場合にも認められた１側耳ならびに耐 側耳の音刺㦸はともに闌值が大きくなつて，両者の間で 差がみられないのは，菅原の行なつた 1 側前庭刺㦸に上 つて偏倚ならびに立涫り反射の異常が垫められたのと異 り，埧線運動刺㦸によつては雨側の前庭迷路が注心゙同じ 強さと同じ性質の刺韩をうけるから，その感覚間值が大 きくなることは，音刺㦸によつて前庭迷路機能が低下す るものと推論した。

以上で煡康成人の面線運動感覚と乞の間值について述 ベてきなが，その臨床的成用の試みとして一側の迷路障

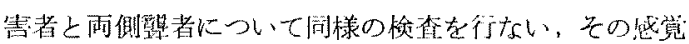
闌值の变化をるた。

一側の迷路機能汇㜔㕩が認められたものは，脊位，腹

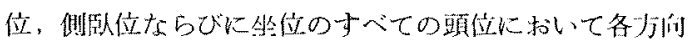

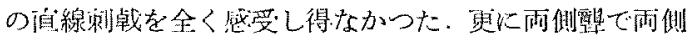
の前涏機能が罢失しているものでは，運動感覚は全く起 らなかつたが，沙庭迷路機能に晎常のないものでは，速

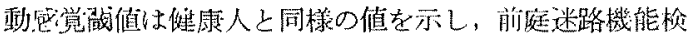
查の成績と一致した。

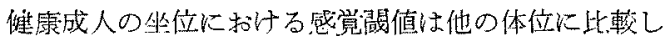
て最も鋭御に感受されたが，一側ならびに邽側の前庭機

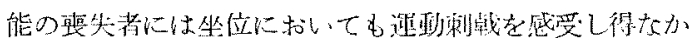

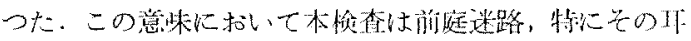
石器の機能检查のた如用らるに便宜なう汒である。 


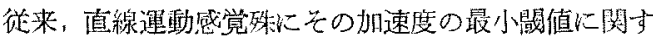

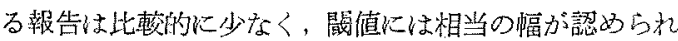
た、著者の行なつた方法は自覚的なものではあるが，被

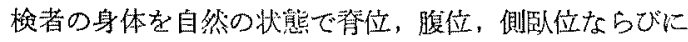
坐位をとらせ，刺㦸の方向を変えて前庭迷路の直線運動

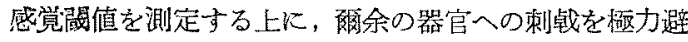
け得たるのと思う。

今後，ブランコ装（Parallel swing）走前庭迷路の

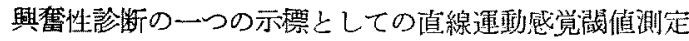
に用い得ることを知つた。

\section{結語}

1) 前庭迷路, 特に耳石器官の機能检查法の一のとし

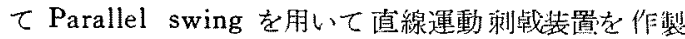
し，春位，湟位，左及び右側卧位，坐位の状態における

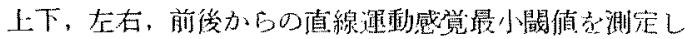
た。

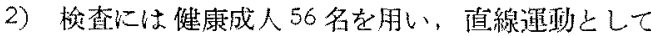

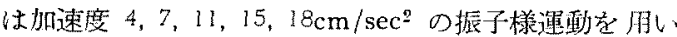
た.

3）各体位に拈ける各方向の刺㦸に対与る直線運動感

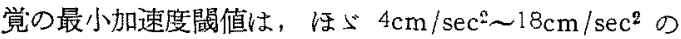
間にあり坐位杂除く他の体位については $4 \mathrm{~cm} / \mathrm{sce}^{2}$ では 全例中の $2.9 \%, 18 \mathrm{~cm} / \mathrm{sec}^{2}$ では全例に扣いて感受され た。

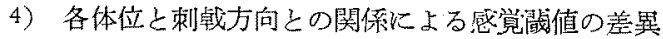
については，坐位の状態が最も解感である。その他の体

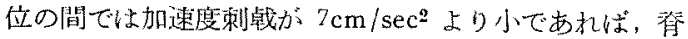
位に和ける上下（長軸力向）及び左右（短軸方向）刺㦸

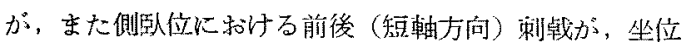

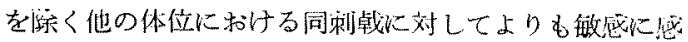
受された，但し加速度が $7 \mathrm{~cm} / \mathrm{sec}^{2}$ 上り本大きくな扎 ば，坐位を除く他の頭位の間に推計学的に有意の差異惊 現れなからた。

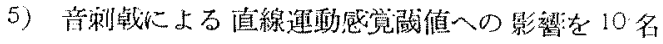
について観察した. その結果 1000c.p.s. て 90db. の音 剌㦸では闘值の上杽が認められた。

6) 臨床応朋例として一側迷路障害者8名ならびに雨

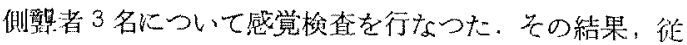
来の梌查法によつて前庭迷路障管と竞断された例では，

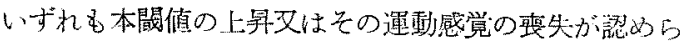
机。

7）本䂥究によつて前庭迷路沈真線運動感觉に站して は敏感であり．前庭迷路特に耳石器の機能梌査にはブラ
ンコ装置による检查が便利で少り，路术上にも応月ので きることを矧つた。

文南

1) Barany, R.: Untersuchungen über den von Vestibularapparat des Ohres reflektorisch ausgelisten rhythmischen Nystagmus und seine Begleiterscheinungen. Monasch. f. Ohren. 40, 352, 1906.

Breuer, J.: Beiträge zur Lehre vom statischen Sinn. wien. Med, Iahrb. 5, 87, 1875.

3) Browen, A.C.: On sense of rotation and anatomy and phy. siology of the semicircular canals of internal ear. J. Anat. and physiol. 8, 327, 1874. 4) Breuer J.: Uber die Funktion der Otolithen-Apparate. Arch. f. d. ges. Physiol. 48, 195, 1890. 5) Chilow, K.L. Über den Funktionszusammenhang des Otolithenapparates und des Bogengangssystems. Z. Hals. Nase. Ohren Heilk. 17, 485, $1927 . \quad 6)$ Flourens, P: Recherches experimentalles sur animaux Vertébrés. 1824. 7) Francis Miokolczy.: Electronystagmog raphic studies of Vestibular funktion. Annals O.R. L. 70, 171, 1. 8) Fitzgerald G., \& Hallpike C.S.: Studies on Human Vestibular Funktion. 1. Observations on the Directional Preponderance of Nystagmus Resulting from Cerebral Lesions. 65, 115 ,

1953. 9) Fischer M.H.: Die Regulationsfunktionen des menschlichen Vestibularapparates und die Zusımmenhänge mit verwandten Funktionen.

Ergebn. d. Physiol. 27, 209. 10) Fischer M.H.u. Wodak E.: Pfluger's Arch. 202, 523, 1924.

Fischkr M.H. u. Kornmuller A.E.: Zbt. f. Sinnesphysiol. 61, 87, 1930. 12) Fukuda $T$, . The Stepping Test, Acta Oto-laryng. 50, 95, 1959.

Fukuda T.: Vertical Writing with Eyes covered. Acta O.L. 50, 95, 1959. 14) Jongkees L.B.W.: Value of the Caloric Test of the Labyrinth. Arch. Otol. 48, 402, 1948 . 15) Jongkees, L. B.W. \& Klign, J.: The threshold of the Vestibular organ. acta O.L. 50, 292, 1952. 16) Jongkees, $L, B . W$.: Positional nystagmus of peripheral origin. J. phy. siol. 110, 447, 1950.17$)$ Jongkees, L.B.W, \& Groen, J.J.: The Sensitivity of the Otoliths. Paries, 1944. 18) Mach, E.: physikulische versuche uber das Gleichgewichtsinn des Menschen. Sitzungsb. d. 
Akad. d Wissensch. 68, 124, $1873 . \quad$ 19) Nylén C.O.: Positional Nystagmus. J. Laryng. \& Otol. 64, 295, 1950. 20) Van Egmond, A.A.J., Groen, J.J. \& Jongkees, L.B.W.: The Function of the Vestibular Organ. S. Karger New-York, $1952 . \quad 21)$ Veits C.: Z. Hals-uw. Heilk. 481, 17, 1832. 22) Veits C.: Arch. Ohrenheilk. 118: 301, 119: 161, 1928. 23) Wodak: Physio-pathologische Probleme des menschlichen Vestibularapparates. Fortschritte der Hals-Nasen-Ohrenheilk. 1, 179, 1953. Howlett, J.G. et al: N.R.C. Canada, Rep. No. C. 2507, 1943, 25) Hulk, J. \& Henkes, H.E.: Die Bedeutung der Otolithen bei der Entstehhung der vestibulo-vegetativen Reflexxe. Pract. ot etc. 12, 65, 1950. 26) Maxwell, S.S.: Labyrinth and Epuilibrium. Philadel. J.B. Lippincott Co. $1923 . \quad 27)$ Noble, R.L.. Symposium on Motion Sickness. Lo-

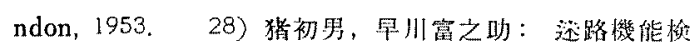
植法としてのカロリーテストの吟味，成候科，23，9， 1954. 29) 大久保清子：温度限振に打叮取石機能

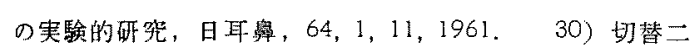

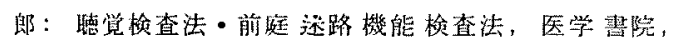
1951. 31) 小谷正推：物理学概説, 窔華房, 1951 . 32) 小洢吉郎，他：限振電図 ENG の技術的諸問題,

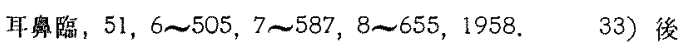
兹敏郎：耳奥咽喉科学，医学畫院，1960.34) 後滕 光治：日本耳鼻咽喉科全書，1巻 1 冊，1953、35) 坂田英治，鈴木渟一，他：頭位変化時に攵られる眼振 (頭位変化眼振) 飞閣与る研究一稵查法の提案, 日耳鼠, $64,8,1402,1961.36)$ 菅原善公: 騷音之前庭述路

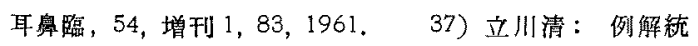

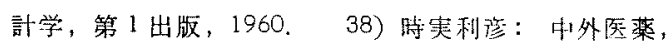
15 巻, 1 号, 1961。39) 時里利彦: 日生理, 13,518,

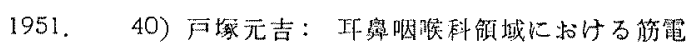

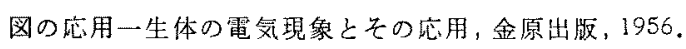
41) 西川弛：所謂内耳性難聴者の前庭㙨能化関寸古研 究，日耳鼻，58，1，30，1955。42）長谷川高敏：述

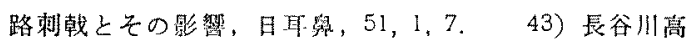
敏: 加速度病, 南条書店.44) 副田精: 速動と平 衡の反射生理, 医学書院, 1957, 45) 滕田敏彦, 估

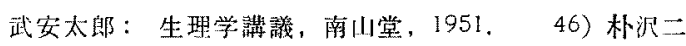
䬦：手動式迴枟法によるクプロメトリ一の检討，日互 鼻，59,7,1027,1956.47) 松永亨：回枟感覚检查 法の研究（振子樣回耺刺戟時の感覚㶼查に就いて），日 耳奥，61，11，1902，1958，48) 三沃敬舆：空醉につ

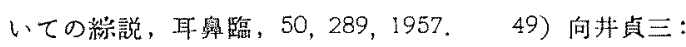

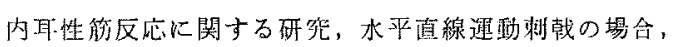

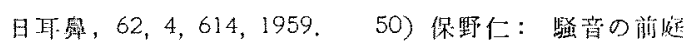
機能に及洼与影瑟，学働科学，27，4，179，1951。 51)

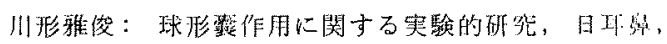
$61,10,1631,1958$. 52) 渡部紫二郎：人体の值線反

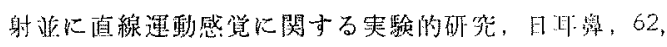
3, 417, 1959. 53) Tait, J. \& McNally, W.J:: Quart. J. Exp. Physiol. 23, 147, 1933. 54) Temkin, J.: Die Schädigung des Ohres durch Lärm und Erschütterung. M-sch. Ohrenhk. usw. 67, 259, 1933. 55) Hennebert, P.E.: Les réactions vestibulaires aux épreuves sinusoidales. Acta Oto-laryng. $46,221,1965$.

（原症到着 $=$ 昭和 37.3 .12 日） 